\title{
A Comprehensive Study on Integration Technique on Air Separation Unit and Gas Turbine for IGCC Power Plant
}

\author{
Aneeq $^{1 *}$, Z.G Fu ${ }^{2}$ \\ School of Energy, Power \& Mechanical Engineering, \\ North China Electric Power University, Beijing 102206, China \\ Hasan Izhar Khan ${ }^{3}$ \\ ${ }^{3}$ Department of Mechanical, \\ Mechatronics \& Manufacturing Engineering (KSK Campus), \\ University of Engineering and Technology, Lahore
}

${ }^{1 *}, 2$ Key Laboratory of Condition Monitoring and Control for Power Plant Equipment of Ministry of Education,

\begin{abstract}
In recent decades, the Chinese economy has been increasing after rapid industrial development, urbanization, and education. Alongside the amelioration, China has to face the stringent environmental policy being a significant emitter of $\mathrm{SO}_{2}, \mathrm{CO}_{2}$, and particulate matter. To overcome the effects of all such pollutants, Integrated Gasification Combined Cycle (IGCC) Technology had proved to be a boon to meet the environmental regulations. IGCC ensures the green use of coal by heating coal in a gasifier with oxygen and steam, producing syngas free from sulfur and carbon dioxide; thus, sustainable energy attained through Bryton cycle and Rankin cycle. For the proposed model, a process simulation tool, EBSILON Professional is considered. The study focused on the integration of gas turbine (GT) with an air separation unit (ASU) at high pressure as it plays a vital role to increase the net efficiency of the plant. For ASU-GT integration, two case studies are considered; 1) the injection rate of $\mathrm{N}_{2}$ with air extraction rate from GT compressor at full, partial and without load, 2) the extraction rate of air with $\mathrm{N}_{2}$ injection at full, partial and without were assayed. The results suggest that the operation of separate ASU or without $\mathrm{N}_{2}$ infusion were not advantageous. However, the $\mathrm{N}_{2}$ injection increased the power output for both the GT and the (ST). Among the solutions of various integration conditions, the most suitable combinations for the cases mentioned in above suggested by comparing them with the base case; where air extraction rate at $80 \%$ and $100 \%$ with nitrogen induction at $100 \%(\mathrm{C17}, \mathrm{C18})$ respectively and nitrogen induction rate at $80 \%$ and $100 \%$ with $95 \%$ air extraction $(\mathrm{C3} 4$, C35) The mass flow rate and turbine inlet temperature (TIT) plays a vital role in the performance of GT. Moreover, no separate compressor designed for further compression of $\mathrm{N}_{2}$ to GT combustor.
\end{abstract}

Keywords: Air separation unit, air extraction, gas turbine, IGCC

\section{INTRODUCTION}

The economic growth of China over the last three decades has been remarkable; its dilation has reached its acme and better amelioration in the use of technology. Over this period, the total energy consumption increased up to $70 \%$ with $75 \%$ increment in coal utilization [1]. Due to which environmental degradation has become the foremost problem not only for China but also for the entire world as it causes global warming, health issues, and the economy. On average, environmental degradation is causing more demise of people than AIDS, breast cancer, tuberculosis, and malaria [2]. Therefore, such inevitable facts ensure the diminution of coal burning for electricity generation. Now, China is the world's largest developing country with extreme consumption of coal and is a carbon emitter. Without diminution, the $\mathrm{CO}_{2}$ production may reach its summit to about $50 \%$ for the following 15 years [3]. At present, $40 \%$ of the world's energy is fueled by the coal burning and is forecasted to supply a strategic share for over the next three decades [4]. Due to the availability of coal for eons, the most expedite technology for the clean burning of coal is IGCC with carbon capture and storage (CCS) which may increase its efficiency to more than $39 \%$. The IGCC technology is far better than pulverized coal combustion (PCC), fluidized bed combustion (FBC) and ultra-supercritical technology due to low emissions of $\mathrm{NO}_{\mathrm{x}}$, $\mathrm{SO}_{\mathrm{x}}, 20 \% \mathrm{CO}_{2}$ production and 20-40\% less use of water [5]. Also, IGCC technology is suitable for a wide variety of coal, whether dry feed or wet feed. The IGCC technology contains various process sections like gasification, syngas cooling, sulfur recovery, $\mathrm{CO}_{2}$ sequestration, GT, heat recovery, and steam generation (HRSG). Ongoing research on IGCC focused on thermal efficiency and design considerations. Keeping in consideration all the benefits from this technology, China owns only two IGCC plants, and none of them proved to be beneficial.

\section{LITERATURE REVIEW}

According to NETL 2007, coal is the primary raw material for IGCC power plants followed by pet coke, biomass, and petroleum as a by-product. Moreover, co-gasification is the most suitable option for electricity generation with such type of power plants. In general, IGCC technology is inherited with complex integration problems and dependency on the various unit process within the plant; thus, providing a big gap for the improvement. The studies on IGCC technology is categorized into three major sections 1) exergy analysis, 2) economic analysis, 3) performance analysis. In all three analysis, IGCC technology is examined with CCS, IGCC with a solid oxidized fuel cell (SOFC) and IGCC with cogasification. The studies on the optimization by taking into 
the exergy analysis can be found in the literature [6-10], where various techniques are considered like extended exergy accounting methodology and exergy analysis with Selexol processes (MEDA, MEA, Methanol, etc.). The studies on the optimization by choosing various modeling approach are [1115]. Similarly, lots of research work is done on IGCC with CCS as indicated in literature [9,16-20], and the hybridization of IGCC with other renewable technologies can be found in various studies [21-23]. A major portion of research focused on the co-gasification for the production of syngas for different chemicals manufacturing, hydrogen production and electricity production with IGCC [24-30]. The integration of cryogenic ASU with GT has been identified as a key process because ASU normally consumes a large amount of power [31] and this integration has a significant impact on total power consumption as well as system net efficiency [32]. The integration of ASU leads to a smooth flow of air and syngas to the GT while reducing NOx formation. There are three types of technologies available for the generation of high purity oxygen that includes pressure swing adsorption, cryogenic distillation, and membrane technology. Above all, the cryogenic technology is the best one for the IGCC where a large amount of oxygen is required to gasify the coal. The power consumption of the ASU unit is very high ultimately affecting the overall efficiency of IGCC [33]. Table 1 illustrates the compendium studies on ASU-GT integration.

\begin{tabular}{|c|c|}
\hline \multicolumn{2}{|c|}{ Table 1: A Literature review on ASU-GT unit for IGCC power plant } \\
\hline Authors & Major results \\
\hline $\begin{array}{l}\text { Wimer et al. } \\
2006[34]\end{array}$ & $\begin{array}{l}\text { The study conducted on air extraction and } \mathrm{N}_{2} \text { injection } \\
\text { by cryogenic ASU technology with low pressure and } \\
\text { elevated pressure and then comparing the results with } \\
\text { membrane-based ASU technology. }\end{array}$ \\
\hline $\begin{array}{l}\text { Emun et al. } 2009 \\
{[5]}\end{array}$ & $\begin{array}{l}\text { The IGCC power plant simulated on Aspen Plus with an } \\
\text { increment in efficiency by operating ASU at } 19 \text { bar with } \\
\text { an } \mathrm{N}_{2} \text { injection to GT at } 55 \% \text { only. However, the study } \\
\text { was not conducted on air extraction rate. }\end{array}$ \\
\hline \multirow[t]{3}{*}{$\begin{array}{l}\text { Cormos et al. } \\
2010[35]\end{array}$} & $\begin{array}{l}\text { Hydrogen and electricity production by IGCC } 400 \mathrm{MW} \\
\text { and CCS } 90 \% \text { carbon capture rate using Aspen Plus. }\end{array}$ \\
\hline & $\begin{array}{c}\text { The thermal efficiency and energy consumption } \\
\text { compared to simulating different cases including the } \\
\text { sensitivity analysis }\end{array}$ \\
\hline & $\begin{array}{l}\text { The extraction of air from the GT compressor is studied } \\
\text { only for Case-1 with ASU unit operating at } 0.237 \mathrm{MPa} \text {. }\end{array}$ \\
\hline \multirow[t]{2}{*}{$\begin{array}{l}\text { He et al. } 2012 \\
{[36]}\end{array}$} & $\begin{array}{c}\text { A mathematical model is developed to study the part } \\
\text { load performance of syngas burning in GT and } \\
\text { comparing it to the base case, i.e., the natural gas } \\
\text { turbine. }\end{array}$ \\
\hline & $\begin{array}{l}\text { The impacts of the variable inlet guide, degree of air } \\
\text { extraction, and the degree of fuel dilution were studied. }\end{array}$ \\
\hline \multirow[t]{3}{*}{$\begin{array}{l}\text { Lee et al. } 2012 \\
\text { [37] }\end{array}$} & $\begin{array}{l}\text { The study contains mathematical optimization called } \\
\text { self-optimized control (SOC) for the elevated pressure } \\
\text { (EP ASU) using gPROMS simulation software. }\end{array}$ \\
\hline & $\begin{array}{l}\text { The study includes the integration of ASU-GT unit by } \\
\text { considering air extraction rate }(27.7 \% \text { \& } 28 \%) \text {, steam } \\
\text { injection rate }(17.3 \% \& 18.2 \%) \text { and } \mathrm{N}_{2} \text { injection rate } \\
(71 \% \& 69.2 \%) \text { only. }\end{array}$ \\
\hline & $\begin{array}{l}\text { The study does not include the comprehensive } \\
\text { integration of ASU-GT unit, and for } \mathrm{N}_{2} \text { injection to GT, } \\
\text { a separate compressor utilized as ASU was operating a } \\
\text { low pressure. }\end{array}$ \\
\hline \multirow[t]{2}{*}{$\begin{array}{l}\text { Han et al. } 2017 \\
\text { [32] }\end{array}$} & $\begin{array}{l}\text { The integration of ASU-GT unit simulated on } \\
\text { Thermoflex software where the detailed study conducted } \\
\text { on air extraction rate along with } \mathrm{N}_{2} \text { induction rate. }\end{array}$ \\
\hline & $\begin{array}{l}\text { Moreover, the ASU unit operated at high pressure, and } \\
\text { for } \mathrm{N}_{2} \text { injection to GT, a separate compressor is utilized. }\end{array}$ \\
\hline
\end{tabular}

\section{PROBLEM FORMULATION}

This study intends to evaluate the ASU-GT unit and find the optimal solution for the most efficient, environmentally friendly, and economical key for commercial IGCC technology with CCS. There are three types of technology available for the production of high purity oxygen by pressure swing adsorption, cryogenic distillation, and membrane technique [32]. Above all, the cryogenic technology is the best one for the IGCC, where a significant amount of oxygen is required to gasify the coal [33]. Therefore, some of the studies conducted on ASU-GT integration as illustrated in Table 1 need further improvements for this unit. Moreover, the elevated pressure cryogenic EP-ASU was used for the production of $\mathrm{O}_{2}$ and $\mathrm{N}_{2}$ as it operates at the pressure equal to the pressure of the GT compressor [34]. The EP-ASU technologies are most preferred when air extraction from the GT compressor is considered. As the ASU is operating at high pressure, it favors the smooth suction for $\mathrm{O}_{2}$ production to their final delivery pressure; thus, reducing power consumption.

Table 2 shows that the $9 \mathrm{H}-\mathrm{GE}$ GT is selected for the firing of syngas and is the most suitable GT with high efficiency and low environmental indicators [38]. The proposed model is simulated on EBSILON Professional; the most suitable and appropriate software for all types of power plants including IGCC, SOFC, and solar power plant with all kinds of Rankin cycle as listed in literature [39-42].

\begin{tabular}{|c|c|c|c|}
\hline \multicolumn{4}{|c|}{ Table 2: Design specification of 9H-GE gas turbine [38] } \\
\hline Output (MW) & $\begin{array}{c}\text { Inlet temperature } \\
\left({ }^{\circ} \mathrm{C}\right)\end{array}$ & $\begin{array}{c}\text { Air flow } \\
(\mathrm{kg} / \mathrm{sec})\end{array}$ & Pressure ratio \\
\hline 480 & 1430 & 685 & 23 \\
\hline
\end{tabular}

The study includes the air extraction rate from the GT and simultaneous operation of ASU. So, this proposed model considered two base cases: 1) the extraction of air from GT compressor (with $\mathrm{N}_{2}$ injection to GT) by running the ASU at without, partial and full load, 2) the injection rate of $\mathrm{N}_{2}$ to GTR by extracting air form GT compressor at without, partial and full load. The extracted air is being utilized for $\mathrm{O}_{2}$ production from ASU to minimize energy consumption. Fig 1 explains the integration technique for ASU-GT section; where the air is removed from the GT compressor, and $\mathrm{N}_{2}$ is injected to GT combustor for different integration combinations. The obtained results are compared with the base case and selected for the most optimized operation of the IGCC power plant. In addition to air extraction, the $\mathrm{N}_{2}$ injection causes a remarkable increment to the overall performance of the IGCC plant by controlling the adiabatic temperature of the flame and reduce the $\mathrm{NO}_{\mathrm{x}}$ formation in GT $[5,32]$. 


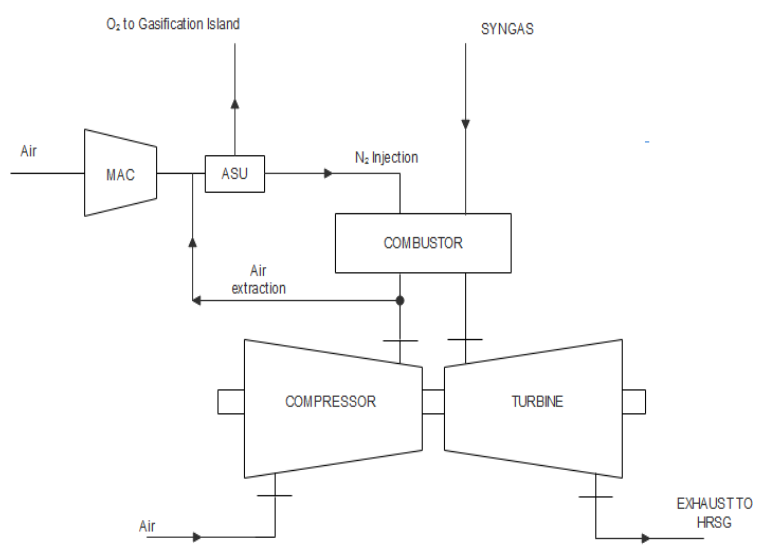

Fig 1: The schematic diagram of ASU-GT unit

Figure 2 explains the various components of IGCC power plant simulated on EBSILON Professional for syngas production, syngas cooling with steam production, $\mathrm{CO}_{2}$ sequestration, GT combustor, Bryton cycle, Rankin cycle, and HRSG units. Although, the application of gasifier is universal for all types of feedstock however dry feed is more beneficial over slurry feed as it lists to agglomeration or clogging of coal thus demands more oxygen and energy consumption [43,44]. The proposed model of IGCC is simulated with EBSILON Professional to generate more efficient and environmentally friendly model [45]. The software is equipped with all types of unit operations like heat exchangers, compressors, pumps, steam turbines, gas turbines, and generators. The EBSILON performs the calculation of the whole process by taking into consideration of energy and mass balance laws for each species, chemical equilibrium, and pressures laws. EBSILON Professional is specifically designed for processing and monitoring of available data, economic evaluation to deviations by providing spot errors, malfunction, and areas of improvement. The simulation for a complex system like power plant is beneficial especially when it comes to studying IGCC technology which involves many chemical and mechanical technologies providing total performance calculations, detailed analysis on chemical quantities and thermodynamic calculations, studying variations in typology and parameters for the whole process.

The assumptions for the simulation model are as follow:

- The model is at steady-state, and the kinetics for char gasification and combustion are included.

- The model considers all the processes occurring in the gasifier, i.e., the coal drying, the coal pyrolysis, the char gasification, and the char combustion. Coal drying and pyrolysis take place instantaneously at the top of the gasifier.

- The solid and gas phase flow in a plug-flow pattern and the pressure drop in the gasifier is neglected.

- The variable bed void-age throughout the gasifier is taken into consideration and temperature of the solid, and the gas is equal inside the gasifier.

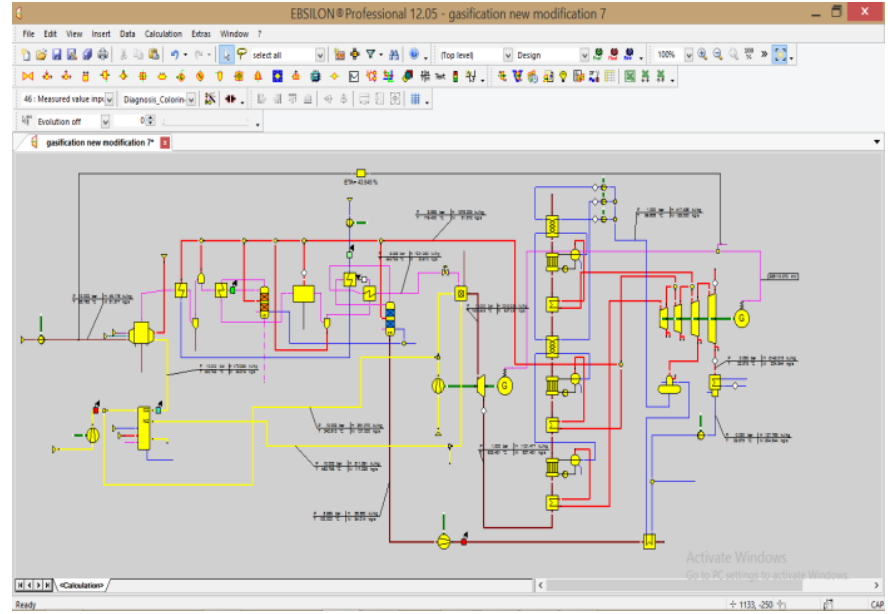

Figure 2: The Process flow diagram of the IGCC power plant by EBSILON Professional

At the initial stage, coal is introduced to the gasification unit as a dry feed with the help of high-pressure nitrogen at 48 bar. The ASU is primarily used to supply oxygen for gasification reaction, and nitrogen was also provided to the combustion chamber of GT. The inlet temperature of steam and oxygen was $600^{\circ} \mathrm{C}$ and $189^{\circ} \mathrm{C}$, respectively $[43,46]$. The syngas produced at equilibrium temperature $1531^{\circ} \mathrm{C}$ and 48 bar pressure $[47,48]$ after rejecting heat and building steam. The cooled syngas enters the $\mathrm{H}_{2} \mathrm{~S}$ removal plant where sulfur production takes place by clause process.

The high-pressure syngas enters the water gas shift reactor for $\mathrm{CO}$ conversion, and finally, $\mathrm{CO}_{2}$ sequestration takes place. The purified syngas enters the GT combustor at $300^{\circ} \mathrm{C}$ for smooth burning and electricity production. After the gasification of coal, the high-temperature syngas enters the gas cooling section where high-temperature steam produced for power generation in the Rankine cycle. The cooled gas comes $\mathrm{H}_{2} \mathrm{~S}$ removal plant and $\mathrm{CO}_{2}$ sequestration plant wherein both cases $95 \%$ separation of said elements takes place. The water gas shift reactor used at high temperature for the conversion of $\mathrm{CO}$ to $\mathrm{CO}_{2}$. The next station for syngas is $\mathrm{CO}_{2}$ sequestration process where the intense amount of gas separates depending upon the composition of coal. The syngas rich in high content of $\mathrm{H}_{2}$ and $\mathrm{CO}$ enters the combustion chamber to generate high-temperature flue gas. The HRSG and combustion chamber produce steam and power from the syngas thermodynamic reaction and hot flue gas from GT combustor. The HRSG unit provides three stages of steam, i.e., high pressure, intermediate pressure, and low pressure for the steam cycle.

\section{METHODOLOGY}

The study on ASU-GT conducted by considering six integration indicators which are explained by the following equations. The air extraction rate is defined to be the ratio of extracted air from GT to the total air flow entering ASU given by the following equation;

$$
X_{A i r}=\frac{\text { Air }_{e x}}{A i r_{e x}+A_{A S U}} \times 100
$$


Where;

Air $_{\mathrm{ex}}=$ rate of air extraction from the GT compressor Air $_{\mathrm{ASU}}=$ Inlet of air from the separate compressor
$\mathrm{E}_{\mathrm{GI}}=$ the energy produced by the gasification island

$\mathrm{E}_{\mathrm{PI}}=$ the electricity generated by the power generation island

$$
E_{n e t}=E_{G T}+E_{S T}-E_{A S U}-E_{a u x}
$$

\begin{tabular}{|c|c|c|c|c|c|c|c|}
\hline \multicolumn{8}{|c|}{ Table 3 Study on air extraction rate at without, partial and full injection of $\mathrm{N}_{2}$} \\
\hline Description & BC & C-1 & C-2 & C-3 & C-4 & C-5 & C-6 \\
\hline $\mathrm{X}_{\text {air }}$ & 0 & 20 & 40 & 50 & 60 & 80 & 100 \\
\hline $\mathrm{X}_{\mathrm{N} 2}$ & 0 & 0 & 0 & 0 & 0 & 0 & 0 \\
\hline Extracted Air kg/sec & 0 & 33.56 & 66.44 & 83.63 & 100.4 & 133.5 & 160.7 \\
\hline Air from compressor kg/sec & 685 & 685 & 685 & 684 & 685 & 685 & 685 \\
\hline Syngas flow $\mathrm{kg} / \mathrm{sec}$ & 30.09 & 29.38 & 28.71 & 28.37 & 28.01 & 27.31 & 26.75 \\
\hline Exhaust gas inlet temperature GT ${ }^{\circ} \mathrm{C}$ & 1430 & 1429 & 1429 & 1430 & 1430 & 1429 & 1429 \\
\hline Coal thermal energy LHV MW th $_{\text {th }}$ & 1258 & 1216 & 1177 & 1151 & 1136 & 1095 & 1063 \\
\hline GT output (MW) & 341.6 & 313.1 & 286.4 & 272.2 & 258.3 & 231.6 & 208.7 \\
\hline ST output (MW) & 213.3 & 216.4 & 219.8 & 220.9 & 222.2 & 225.5 & 227.2 \\
\hline Gross output (MW) & 554 & 529 & 506.2 & 493.1 & 480.5 & 457.1 & 435.9 \\
\hline Total Auxiliary (MW) & 153.5 & 129.2 & 110.3 & 100.5 & 89.5 & 62.1 & 31.5 \\
\hline Net output & 401.8 & 400.8 & 395.7 & 393.2 & 391.7 & 394.1 & 405.0 \\
\hline Gross efficiency \% & 44.11 & 43.55 & 42.97 & 42.65 & 42.34 & 41.64 & 41.06 \\
\hline Net efficiency \% & 31.92 & 32.93 & 33.60 & 33.97 & 34.46 & 35.97 & 38.09 \\
\hline Description & BC & C-7 & C-8 & C-9 & C-10 & C-11 & C-12 \\
\hline $\mathrm{X}_{\mathrm{air}}$ & 0 & 0 & 20 & 40 & 60 & 80 & 100 \\
\hline $\mathrm{X}_{\mathrm{N} 2}$ & 0 & 50 & 50 & 50 & 50 & 50 & 50 \\
\hline Extracted Air kg/sec & 0 & 33.56 & 66.44 & 83.63 & 100.4 & 133.5 & 160.7 \\
\hline Air from the compressor $\mathrm{kg} / \mathrm{sec}$ & 685 & 685 & 685 & 685 & 685 & 685 & 685 \\
\hline Syngas flow kg/sec & 30.09 & 30.91 & 30.30 & 29.66 & 29.01 & 28.39 & 27.95 \\
\hline Exhaust gas inlet temperature GT ${ }^{\circ} \mathrm{C}$ & 1430 & 1430 & 1430 & 1430 & 1430 & 1429 & 1429 \\
\hline Coal thermal energy LHV $\mathrm{MW}_{\text {th }}$ & 1258 & 1216 & 1177 & 1157 & 1136 & 1095 & 1063 \\
\hline GT output & 341.6 & 390.2 & 362.8 & 335.6 & 307.8 & 280.0 & 258.3 \\
\hline ST output & 213.3 & 209.7 & 212.6 & 215.5 & 218.2 & 220.7 & 222.5 \\
\hline Gross output & 554.9 & 604.9 & 575.4 & 551.1 & 526 & 500.7 & 480.8 \\
\hline Total Auxiliary MW & 153.5 & 154.6 & 130.4 & 111.6 & 90.84 & 63.30 & 33.07 \\
\hline Net output & 401.8 & 445.5 & 445.0 & 439.5 & 435.3 & 437.5 & 447.8 \\
\hline Gross efficiency \% & 44.11 & 47.18 & 45.41 & 44.69 & 44.02 & 43.22 & 42.43 \\
\hline Net efficiency \% & 31.92 & 35.02 & 35.00 & 35.64 & 36.42 & 37.76 & 39.51 \\
\hline Description & BC & C-13 & C-14 & C-15 & C-16 & C-17 & C-18 \\
\hline $\mathrm{X}_{\text {air }}$ & 0 & 0 & 20 & 40 & 60 & 80 & 100 \\
\hline $\mathrm{X}_{\mathrm{N} 2}$ & 0 & 100 & 100 & 100 & 100 & 100 & 100 \\
\hline Extracted Air kg/sec & 0 & 33.56 & 66.44 & 83.63 & 100.4 & 133.5 & 160.7 \\
\hline Air from the compressor $\mathrm{kg} / \mathrm{sec}$ & 685 & 685 & 685 & 685 & 685 & 685 & 685 \\
\hline Syngas flow kg/sec & 30.09 & 31.70 & 31.17 & 30.58 & 30.01 & 29.49 & 29.15 \\
\hline Exhaust gas inlet temperature GT ${ }^{\circ} \mathrm{C}$ & 1430 & 1430.1 & 1430.2 & 1429.8 & 1431.6 & 1431.2 & 14295 \\
\hline Coal thermal energy LHV $\mathrm{MW}_{\mathrm{th}}$ & 1258 & 1355 & 1323 & 1287 & 1253 & 1223 & 1203 \\
\hline GT output (MW) & 341.6 & 438.2 & 411.0 & 384.0 & 357.0 & 329.9 & 307.8 \\
\hline ST output (MW) & 213.3 & 205.9 & 208.5 & 211.2 & 214.0 & 216.2 & 217.4 \\
\hline Gross output (MW) & 554.9 & 644.1 & 649.5 & 595.2 & 571 & 546.1 & 525.2 \\
\hline Total Auxiliary (MW) & 153.5 & 155.6 & 131.6 & 112.8 & 92.14 & 64.73 & 34.62 \\
\hline Net output (MW) & 401.8 & 488.5 & 487.9 & 482.5 & 478.9 & 481.4 & 490.6 \\
\hline Gross efficiency $\%$ & 44.11 & 47.52 & 46.82 & 46.23 & 45.54 & 44.64 & 43.65 \\
\hline Net efficiency \% & 31.92 & 36.04 & 36.88 & 37.47 & 38.19 & 39.35 & 40.77 \\
\hline
\end{tabular}

$$
I N_{\text {nitrogen }}=\frac{N_{2, \text { in }}}{N_{2, \text { total }}} \times 100
$$

Where;

$\mathrm{N}_{2, \text { in }}=$ Injection of air to the GT combustor from the ASU

$\mathrm{N}_{2, \text { total }}=$ the total amount of $\mathrm{N}_{2}$ produced by ASU

$$
E_{\text {aux }}=E_{G I}+E_{C O 2}+E_{P I}
$$

Where;

$\mathrm{E}_{\text {aux }}=$ the amount of power utilized by all auxiliaries equipment is within in IGCC plant except ASU
Where;

$\mathrm{E}_{\mathrm{net}}=$ the net electricity provided by the proposed system

$\mathrm{E}_{\mathrm{GT}}=$ the electricity generated by the GT

$\mathrm{E}_{\mathrm{ST}}=$ the electricity generated by the ST

$\mathrm{E}_{\mathrm{ASU}}=$ the power consumed by the ASU

$\mathrm{E}_{\mathrm{aux}}=$ the power consumed by the remaining auxiliaries

$$
\eta_{\text {net }}=\frac{E_{\text {net }}}{E_{\text {Coal }}} \times 100
$$

The net efficiency is defined as the ratio of energy produced by the plant to the thermal energy of the coal.

Where $\mathrm{E}_{\text {net }}$ is the net electricity generated by the plant and $E_{\text {coal }}$ is the thermal energy of Coal. 


\begin{tabular}{|c|c|c|c|c|c|c|c|}
\hline Descrintion & $\mathrm{BC}$ & & & & & & \\
\hline $\mathrm{X}_{\text {air }}$ & 0 & 0 & 0 & 0 & 0 & 0 & 0 \\
\hline$X_{\mathrm{N} 2}$ & 0 & 20 & 40 & 50 & 60 & 80 & 100 \\
\hline Extracted air kg/sec & 0 & 0 & 0 & 0 & 0 & 0 & 0 \\
\hline Air from compressor kg/sec & 685 & 685 & 685 & 685 & 685 & 685 & 685 \\
\hline Syngas flow $\mathrm{kg} / \mathrm{sec}$ & 30.09 & 30.44 & 30.76 & 30.91 & 31.08 & 31.38 & 31.69 \\
\hline Exhaust gas inlet temperature $\mathrm{GT}^{\circ} \mathrm{C}$ & 1430.3 & 1431.5 & 1431.4 & 1430.7 & 1431.2 & 1429.3 & 1429.5 \\
\hline Coal thermal energy LHV $\left(\mathrm{MW}_{\text {th }}\right)$ & 1258.2 & 1279.3 & 1298.6 & 1307.6 & 1317.9 & 1335.7 & 1354.9 \\
\hline GT output (MW) & 341 & 361.5 & 380.88 & 390.23 & 400.1 & 418.7 & 437.9 \\
\hline ST output (MW) & 213 & 212.1 & 210.5 & 209.79 & 209.1 & 207.5 & 205.9 \\
\hline Gross output (MW) & 554 & 573.65 & 591.44 & 600.02 & 609.18 & 626.3 & 643.98 \\
\hline Total Auxiliary (MW) & 153.5 & 153.9 & 154.4 & 154.6 & 154.8 & 155.2 & 155.6 \\
\hline Net output (MW) & 401.8 & 419.6 & 437.0 & 445.40 & 454.3 & 471.1 & 488.3 \\
\hline Gross efficiency \% & 44.11 & 44.84 & 45.54 & 45.88 & 46.22 & 46.88 & 47.52 \\
\hline Net efficiency \% & 31.92 & 32.80 & 33.65 & 34.06 & 34.47 & 35.26 & 36.03 \\
\hline Description & BC & C-25 & $\mathrm{C}-26$ & C-27 & C-28 & C-29 & C-30 \\
\hline$X_{\text {air }}$ & 0 & 50 & 50 & 50 & 50 & 50 & 50 \\
\hline $\mathrm{X}_{\mathrm{N} 2}$ & 0 & 20 & 40 & 50 & 60 & 80 & 100 \\
\hline Extracted Air kg/sec & 0 & 83.57 & 83.57 & 83.57 & 83.57 & 83.57 & 83.57 \\
\hline Air from the compressor $\mathrm{kg} / \mathrm{sec}$ & 685 & 685 & 685 & 685 & 685 & 685 & 685 \\
\hline Syngas flow $\mathrm{kg} / \mathrm{sec}$ & 30.09 & 28.37 & 28.74 & 29.13 & 29.52 & 29.91 & 30.28 \\
\hline Exhaust gas inlet temperature $\mathrm{GT}^{\circ} \mathrm{C}$ & 1430 & 1430.9 & 1430.1 & 1430.4 & 1430.7 & 1430.5 & 14304 \\
\hline Coal thermal energy LHV MW MW $_{\text {th }}$ & 1258 & 1157.7 & 1179.5 & 1202.3 & 1225.1 & 1247.4 & 12699 \\
\hline GT output & 341.6 & 272.9 & 292.1 & 311.7 & 331.4 & 350.8 & 370.3 \\
\hline ST output & 213.3 & 220.9 & 219.3 & 217.7 & 216.1 & 214.4 & 212.6 \\
\hline Gross output & 554.9 & 493.8 & 511.4 & 529.5 & 547.5 & 565.2 & 583.0 \\
\hline Total Auxiliary MW & 153.5 & 100.5 & 101.0 & 101.5 & 102.06 & 102.55 & 103.5 \\
\hline Net output & 401.8 & 393.3 & 410.4 & 427.9 & 445.4 & 462.7 & 479.9 \\
\hline Gross efficiency \% & 44.11 & 42.65 & 43.36 & 44.03 & 44.69 & 45.31 & 45.90 \\
\hline Net efficiency \% & 31.92 & 33.97 & 34.79 & 35.59 & 36.36 & 37.09 & 37.79 \\
\hline Description & BC & C-31 & C-32 & C-33 & C-34 & C-35 & C-36 \\
\hline $\mathrm{X}_{\mathrm{air}}$ & 0 & 95 & 95 & 95 & 95 & 95 & 95 \\
\hline $\mathrm{X}_{\mathrm{N} 2}$ & 0 & 20 & 40 & 50 & 60 & 80 & 100 \\
\hline Extracted Air kg/sec & 0 & 160.7 & 160.7 & 160.7 & 160.7 & 160.7 & 160.7 \\
\hline Air from the compressor $\mathrm{kg} / \mathrm{sec}$ & 685 & 685 & 685 & 685 & 685 & 685 & 685 \\
\hline Syngas flow $\mathrm{kg} / \mathrm{sec}$ & 30.09 & 26.76 & 27.25 & 27.72 & 28.20 & 28.68 & 29.16 \\
\hline Exhaust gas inlet temperature GT ${ }^{\circ} \mathrm{C}$ & 1430.3 & 1430.8 & 1431.1 & 1430.5 & 1430.3 & 1430.1 & 14304 \\
\hline Coal thermal energy LHV MW & 1258 & 1063.8 & 1092.2 & 1119.8 & 1147.7 & 1175.6 & 12041 \\
\hline GT output MWe & 341.8 & 209.1 & 229.1 & 248.7 & 268.4 & 288.2 & 308.2 \\
\hline ST output MWe & 213.5 & 227.7 & 225.6 & 223.6 & 221.5 & 219.5 & 217.4 \\
\hline Gross output MWe & 555.3 & 436.8 & 454.7 & 472.3 & 490.1 & 507.7 & 525.6 \\
\hline Total Auxiliary MWe & 153.5 & 31.54 & 32.17 & 32.78 & 33.396 & 34.01 & 34.63 \\
\hline Net output & 401.8 & 405.3 & 422.5 & 439.54 & 456.63 & 473.72 & 491.2 \\
\hline Gross efficiency \% & 44.11 & 41.06 & 41.63 & 42.17 & 42.69 & 43.18 & 43.65 \\
\hline Net efficiency \% & 31.92 & 38.09 & 38.68 & 39.24 & 39.78 & 40.29 & 40.78 \\
\hline
\end{tabular}

\section{RESULTS AND DISCUSSION}

A. Study on air extraction rate $X_{\text {air }}$ without, partial and full injection of $\mathrm{N}_{2}$

Table 3 illustrates the effects of air extraction rate at conditions of no $\mathrm{N}_{2}$ infusion, partial $50 \%$ injection, and complete $100 \%$ injection. For the first case, no $\mathrm{N}_{2}$ injection was considered where the remarkable drop is observed in $\mathrm{E}_{\mathrm{GT}}$ output due to air extraction from 0 to $100 \%$ decreased to the combustor. The air extraction causes an increase in temperature, in order to maintain TIT temperature, the flow of syngas regulated. Thus, creating a significant loss to GT output and a firm agreement to Han et al. [32] and Cormos et al. [35]. However, it observed that the production of ST kept on increasing as the air extraction flow increases. Although the mass flow rate across the GT decreased, the sensible heat and TIT of GT remained constant due to which the ST output slightly increased. The extraction of air minimized the load consumption on ASU, but the overall performance of the plant has significantly affected by this technique. The air extraction from the GT compressor observed with almost the same trend at partial $50 \%$ induction of $\mathrm{N}_{2}$ to GT combustor. As the mass flow rate of air extracted from $0 \%$ to $100 \%$ increases; the power output by GT decreases due to the reduction of overall flow across the GT. At $0 \%$ and $100 \%$ $\mathrm{X}_{\mathrm{air}}$, the power produced by GT was 390.2 MW and 258.3 MW and by ST was 209.7 MW and 222.5 respectively. However, the stability in TIT and sensible heat of exhaust gas causes a slight increase in the performance of ST, which contradicts from the study in the literature [32]. Similarly, the syngas flow is also regulated with TIT restriction. For cases between, $\mathrm{C} 13-\mathrm{C} 18$, the same trend was observed in required indicators at full injection of $\mathrm{N}_{2}$ to GT combustor with air extraction growth from $0 \%$ to $100 \%$ but the power augmented effect for this case is remarkably apparent due to the large flow of exhaust at $0 \%$ extraction of air but goes on decreasing by increasing air extraction flow. The full injection of $\mathrm{N}_{2}$ causes the maximum output of GT. For each case, the flow across the GT draws significant loss to the power output with $\mathrm{X}_{\text {air }}$ growth. 
B. Study on $\mathrm{N}_{2}$ injection at without, partial and full load

Table 4 shows the injection rate of $\mathrm{N}_{2}$ from $0 \%$ to $100 \%$ to GT combustor against without, a partial and complete amount of air extracted from the primary air compressor (PAC) of GT. In the case $\mathrm{C} 19-\mathrm{C} 24$, the $\mathrm{N}_{2}$ injection rate studied against without air extraction from the primary air compressor or in other words the ASU operated at its full capacity. It is seen, as the $\mathrm{N}_{2}$ induction increases, the output power across GT increases. Conversely, the ST power output decreases as the sensible heat decreases with the introduction of $\mathrm{N}_{2}$ injection. The elemental $\mathrm{N}_{2}$ causes a drop in temperature during the burning of syngas inside the combustion chamber [5]. In most cases, the temperature of the flame is regulated against by nitrogen. Similarly, for cases, $\mathrm{C} 25-\mathrm{C} 30$, where the ASU unit is running at 50\% $(50 \%$ extraction of air from PAC), the same trend in the power output of GT was substantially reduced as compared to Case C4. Although, the power output increased with nitrogen induction; however, the overall flow across the GT has diminished. In the final case study of case C6, the nitrogen induction rate was observed by operating ASU at full load, i.e. $100 \%$ extraction from PAC. The overall output produced by GT and ST reduced due to the reduction of the flow of fresh air from the PAC. The syngas flow rate was regulated to meet the temperature limitation for GT, and in Table 4, the syngas flow rate increases as the air extraction flow increases.

\section{CONCLUSION}

The purpose of the study is to evaluate the ASU-GT integration by considering the air extraction from the PAC and nitrogen induction to GT combustor. The whole research comes up with the following main points:

1. The study explains the importance of air extraction that caused a significant power production on GT as well as ST. The air extraction rate plays a vital role in process optimization if the ASU is operating at elevated pressure.

2. The air extraction causes a remarkable change in the performance of GT as compared to nitrogen induction, but the combination of both can lead to optimized efficiency.

3. In Table 3, the syngas flow rate decreased to meet TIT limitations against the increase in air extraction rate. On the Contrary, in Table 4, the syngas flow increased because of the induction of $\mathrm{N}_{2}$ causes the mitigation of combustion temperature of exhaust gas.

4. By comparing with the base case, four optimized solutions were obtained by ASU-GT integration, i.e., $\mathrm{C} 17, \mathrm{C} 18, \mathrm{C} 34$, and $\mathrm{C} 35$, where the gross efficiency and net efficiency is remarkably high.

\section{ACKNOWLEDGMENT}

This research was funded by the Beijing Natural Science Foundation (Grant No. 3162030) and Key Laboratory of Condition Monitoring and Control for Power Plant Equipment of Ministry of Education, North China Electric Power University.

\section{REFERENCE}

[1] The World Bank / State Environmental Protection Administration, "Cost of Pollution in China Conference Edition Cost of Pollution in China," World Bank, vol. 86, no. 10, p. 128, 2007.

[2] R. A. Rohde and R. A. Muller, "Air pollution in China: mapping of concentrations and sources," PLoS One, vol. 10, no. 8, p. e0135749, 2015 .

[3] Z. Liu, "China's Carbon Emissions Report 2016: Regional Carbon Emissions and the Implication for China's Low Carbon Development," 2016.

[4] World Energy Council, "World Energy Resources 2016," World Energy Resour. 2016, pp. 1-33, 2016.

[5] F. Emun, M. Gadalla, T. Majozi, and D. Boer, "Integrated gasification combined cycle (IGCC) process simulation and optimization," Comput. Chem. Eng., vol. 34, no. 3, pp. 331-338, 2010

[6] W. S. Lee, J. C. Lee, H. T. Oh, S. W. Baek, M. Oh, and C. H. Lee, "Performance, economic and exergy analyses of carbon capture processes for a $300 \mathrm{MW}$ class integrated gasification combined cycle power plant," Energy, vol. 134, pp. 731-742, 2017.

[7] C. Seckin, "Extended Exergy Accounting analysis of IGCC process - Determination of environmental remediation cost of refinery and coke processing waste," J. Clean. Prod., vol. 119, pp. 178-186, 2015

[8] C. Kunze, K. Riedl, and H. Spliethoff, "Structured exergy analysis of an integrated gasification combined cycle (IGCC) plant with carbon capture," Energy, vol. 36, no. 3, pp. 1480-1487, 2011.

[9] M. Kawabata, O. Kurata, N. Iki, A. Tsutsumi, and H. Furutani, "System modeling of exergy recuperated IGCC system with pre- and post-combustion CO2 capture," Appl. Therm. Eng., vol. 54, no. 1, pp. 310-318, 2013

[10] Y. Cao, B. He, G. Ding, L. Su, and Z. Duan, "Energy and exergy investigation on two improved IGCC power plants with differen CO2 capture schemes," Energy, vol. 140, pp. 47-57, 2017.

[11] B. W. Bequette, "Model Predictive Control of Integrated Gasification Combined Cycle Power," no. September 2010, 2010.

[12] Y. Li, X. Jiang, X. Huang, J. Jia, and J. Tong, "Optimization of high-pressure shell-and-tube heat exchanger for syngas cooling in an IGCC," Int. J. Heat Mass Transf., vol. 53, no. 21-22, pp. 4543 4551, 2010 .

[13] Y. Lang, S. E. Zitney, and L. T. Biegler, "Optimization of IGCC processes with reduced order CFD models," Comput. Chem. Eng. vol. 35 , no. 9, pp. 1705-1717, 2011.

[14] J. Xiong, H. Zhao, C. Zhang, C. Zheng, and P. B. Luh, "Thermoeconomic operation optimization of a coal-fired power plant," Energy, vol. 42, no. 1, pp. 486-496, 2012.

[15] C. Paper, R. Anapagaddi, G. Davison, and T. Madras, "Simulation of Integrated Gasification Combined cycle ( IGCC )," no. April 2016.

[16] S. Heil, C. Brunhuber, K. Link, J. Kittel, and B. Meyer, "Dynamic Modelling of CO2-removal units for an IGCC power plant," pp. 77 $85,2009$.

[17] A. M. Cormos and C. C. Cormos, "Techno-economic evaluations of post-combustion $\mathrm{CO} 2$ capture from sub- and super-critical circulated fluidized bed combustion (CFBC) power plants," Appl. Therm. Eng., vol. 127, pp. 106-115, 2017.

[18] J. Franz, P. Maas, and V. Scherer, "Economic evaluation of precombustion CO 2 -capture in IGCC power plants by porous ceramic membranes," Appl. Energy, vol. 130, pp. 1-11, 2014.

[19] A. Bardi and G. Pannocchia, "A multivariable approach for control system optimization of IGCC with CCS in DECARBit project,' Energy Procedia, vol. 23, no. 50, pp. 370-380, 2012.

[20] T. J. Falcke, A. F. A. Hoadley, D. J. Brennan, and S. E. Sinclair, "The sustainability of clean coal technology: IGCC with/withou CCS," Process Saf. Environ. Prot., vol. 89, no. 1, pp. 41-52, 2011.

[21] M. Liszka, T. Malik, M. Budnik, and A. Zie, "Comparison of IGCC ( integrated gasification combined cycle ) and CFB ( circulating fluidized bed ) cogeneration plants equipped with CO 2 removal," vol. 58, 2013

[22] S. Obara, J. Morel, M. Okada, and K. Kobayashi, "Study on the load following characteristics of a distributed IGCC for independent microgrid," Energy, vol. 115, pp. 13-25, 2016.

[23] F. Arroyo, O. Font, J. M. Chimenos, C. Fernández-Pereira, X. Querol, and P. Coca, "IGCC fly ash valorization. Optimization of Ge 
and Ga recovery for an industrial application," Fuel Process. Technol., vol. 124, pp. 222-227, 2014

[24] C. C. Cormos, "Techno-economic and environmental analysis of hydrogen and power co-generation based on co-gasification of coal and biomass / solid wastes with carbon capture," Chem. Eng. Trans., vol. 37, pp. 139-144, 2014.

[25] L. P. R. Pala, Q. Wang, G. Kolb, and V. Hessel, "Steam gasification of biomass with subsequent syngas adjustment using shift reaction for syngas production: An Aspen Plus model," Renew. Energy, vol. 101, pp. 484-492, 2017.

[26] A. J. Keche, A. P. R. Gaddale, and R. G. Tated, "Simulation of biomass gasification in downdraft gasifier for different biomass fuels using ASPEN PLUS," Clean Technol. Environ. Policy, vol. 17, no. 2, pp. 465-473, 2015.

[27] H. Zheng, N. Kaliyan, and R. V. Morey, "Aspen Plus simulation of biomass integrated gasification combined cycle systems at corn ethanol plants," Biomass and Bioenergy, vol. 56, pp. 197-210, 2013.

[28] W. Doherty, A. Reynolds, and D. Kennedy, "Aspen plus simulation of biomass gasification in steam blown dual fluidized bed," Mater. Process Energy, pp. 212-220, 2013.

[29] M. J. Kabir, A. A. Chowdhury, and M. G. Rasul, "Pyrolysis of municipal green waste: A modeling, simulation, and experimental analysis," Energies, vol. 8, no. 8, pp. 7522-7541, 2015.

[30] R. Fatoni, S. Gajjar, S. Gupta, S. Handa, and A. Elkamel, "Modeling Biomass Gasification in a Fluidized Bed Reactor," Int. Conf. Ind. Eng. Oper. Manag., pp. 1047-1056, 2014.

[31] A.. Smith and J. Klosek, "A review of air separation technologies and their integration with energy conversion processes," Fuel Process. Technol., vol. 70, no. 2, pp. 115-134, 2001.

[32] L. Han, G. Deng, Z. Li, Q. Wang, and K. E. Ileleji, "Integration optimization of elevated pressure air separation unit with the gas turbine in an IGCC power plant," vol. 110, pp. 1525-1532, 2017.

[33] P. Basu et al., "Oxy-fuel combustion of pulverized coal: Characterization, fundamentals, stabilization and CFD modeling," $J$. Philos. Log., vol. 38, no. 3, pp. 6657-6670, 2016.

[34] J. G. Wimer, D. Keairns, E. L. Parsons, and J. a. Ruether, "Integration of Gas Turbines Adapted for Syngas Fuel With Cryogenic and Membrane-Based Air Separation Units: Issues to Consider for System Studies," J. Eng. Gas Turbines Power, vol. 128 , no. 2, p. 271, 2006

[35] C. C. Cormos, "Evaluation of energy integration aspects for IGCCbased hydrogen and electricity co-production with carbon capture and storage," Int. J. Hydrogen Energy, vol. 35, no. 14, pp. 7485 7497, 2010

[36] F. He, Z. Li, P. Liu, L. Ma, and E. N. Pistikopoulos, "Operation window and part-load performance study of a syngas fired gas turbine," Appl. Energy, vol. 89, no. 1, pp. 133-141, 2012.

[37] K. Roh, H. Lee, and J. H. Lee, "Modeling and control studies for the elevated pressure air separation unit in an IGCC power plant," AIChE 2012 - 2012 AIChE Annu. Meet. Conf. Proc., 2012.

[38] R. K. Matta, G. D. Mercer, and R. S. Tuthill, "the 21st Century -."

[39] F. Biegler-könig and P. Deeskow, "Fast simulation and optimization with neural networks," vol. 4, no. 1, 2005.
[40] T. Vogel, G. Oeljeklaus, K. Görner, J. Dersch, and T. Polklas, "Hybridization of parabolic trough power plants with natural gas,' Energy Procedia, vol. 49, pp. 1238-1247, 2013.

[41] R. Pawellek, S. Ketek, and I. T. Gmbh, "Modelling IGCC Plants Using the Simulation Tool Ebsilon Professional."

[42] M. Seitz, "Thermodynamische Simulation und Optimierung von Betriebszyklen bei solarthermischen Kraftwerken mit Flüssigsalzen als Wärmeträgermedien," no. September, p. 198, 2012.

[43] M. Gazzani, G. Manzolini, E. MacChi, and A. F. Ghoniem, "Reduced order modeling of the Shell-Prenflo entrained flow gasifier," Fuel, vol. 104, pp. 822-837, 2013.

[44] U. Ahmed, U. Zahid, Y. Su, C. Lee, and C. Han, "Chemica Engineering and Processing: Process Intensification IGCC process intensification for simultaneous power generation and $\mathrm{CO} 2$ capture," vol. 101, pp. 72-86, 2016.

[45] "PowerGen_2011_Paper_SR-SPM_en.pdf.".

[46] R. Hoya and C. Fushimi, "Thermal efficiency of advanced integrated coal gasification combined cycle power generation systems with low-temperature gasifier, gas cleaning and CO2 capturing units,' Fuel Process. Technol., vol. 164, pp. 80-91, 2017.

[47] E. J. O. Promes, T. Woudstra, L. Schoenmakers, V. Oldenbroek, A Thallam Thattai, and P. V. Aravind, "Thermodynamic evaluation and experimental validation of 253MW Integrated Coal Gasification Combined Cycle power plant in Buggenum, Netherlands," Appl. Energy, vol. 155, no. June 2013, pp. 181-194, 2015.

[48] L. Riboldi and O. Bolland, "Comprehensive analysis on the performance of an IGCC plant with a PSA process integrated for CO2 capture," Int. J. Green. Gas Control, vol. 43, pp. 57-69, 2015. 